\title{
The influence of policy networks on policy output. A comparison of organic farming policy in the Czech Republic and Poland
}

Heidrun Moschitz, Matthias Stolze, Research Institute of Organic Agriculture, Frick, Switzerland Email: heidrun.moschitz@fibl.org

\begin{abstract}
Although, at the time of accession to the EU, organic farming policies formally were equally developed in the Czech Republic and Poland, a closer investigation reveals some variation. This paper takes a policy network perspective to explore the policy differences between these two countries. Common network themes are used to link networks with policy output. It is argued that the capacity of the organic sector and its structural organization, its cohesion, and the relationship between organic interest groups and the government affect the political discourse, and, in consequence, how organic farming policy is elaborated.
\end{abstract}

KEY WORDS: Central and Eastern European countries, organic farming, policy networks, policy output

\section{INTRODUCTION}

Organic agriculture began to develop both in the Czech Republic and in Poland in the early 1990s. These two countries show many similarities. After the fall of the 'Iron Curtain' they transformed their political systems from socialist to capitalist structures, and are now multi-party parliamentary democratic systems. They are situated in a similar geographical environment and agriculture is faced with similar climatic conditions. The most important trigger for organic farming (policy) development in Poland and the Czech Republic was the accession process to the EU starting in 1997 (Prazan et al., 2004). From then on, the countries were equally eligible for the same European funds and financial 
assistance to support the transformation and accession process. Since May 2004 they are full members of the EU, and accordingly, the Common Agricultural Policy (CAP) is valid for both countries, and as part of the CAP - the EU organic farming rules. At the time of their accession, both the Czech Republic and Poland thus formally complied with the EU organic farming policy, but, as we will see, the policy output in the two countries differed.

The aim of this paper is to explore the organic farming policies in the Czech Republic and Poland and to explain the differences between them. We will show what a policy network perspective can contribute to understanding the differences in policy outputs. Thereby, we understand policy output as the specific measures (policy instruments) a government implements to support organic farming (Stolze and Lampkin, 2009). It is described here both in terms of policy content and the timeliness of transposition from EU policy. Our focus is on the Council Regulation (EEC) No. 2092/91 defining organic agriculture and Council Regulation (EC) No. 1257/99 providing the basis for financial support of organic farmers.

This paper is divided into five parts. First, we discuss the policy network approach before introducing the methods used. Third, we explore the Czech and the Polish organic farming policy outputs in detail. The article continues by comparing the organic farming policy networks in the Czech Republic and Poland. Subsequently, we discuss what the policy network perspective contributes to explaining the differences in organic farming policy output in these two countries. The data presented mainly refers to the end of 2003 / beginning of 2004 - the period in which the network analysis was conducted.

\section{POLICY MAKING, NETWORKS, AND ANALYSIS}

In an increasingly complex society policy making takes place in a targeted cooperation between the state and societal actors. These societal actors represent organized interests on which they act within an institutional framework defined by the state. In policy analysis, the relationships built up between these organized interests and the state can be conceived of as policy networks. Such networks develop, because actors within a particular policy field depend upon each others' resources. The state offers influence in the policy process to the societal actors who, in turn, provide legitimisation and 
information to the state actors and support policy implementation. The so-formed networks are then part of the context in which individual actors have to take their decisions. Network structures thus represent options and constraints for individual actions (Knoke, 1996).

\section{A classification of policy networks}

From a structural perspective, it is the type of network that influences policy results (Marin and Mayntz, 1991; Rhodes, R.A.W. and Marsh, 1992). A closed network consisting of a limited number of actors with shared ideology, values, and broad policy preferences will produce a different policy result than a network that is open to numerous interest groups with diverging values and conflicting preferences. Different authors have developed comprehensive network typologies (see e.g. Rhodes and Marsh, 1992; Van Waarden, 1992). The benefit of such typologies is that they offer a useful tool to order and categorize information and to describe and classify policy subsystems which can then be compared with each other, including the question of their influence on policy output. However, comprehensive network typologies are often difficult to apply empirically. On the one hand, the 'dimensions' forming the basis for the categories are sometimes difficult to operationalize, and on the other hand, the complexity of some typologies (e.g. Van Waarden (1992) uses eleven network types) is unsuitable for an empirical analysis (Sciarini, 1995). For these reasons we follow (Sciarini, 1995; 1996) and choose a fairly general classification of networks developed by Kriesi (1994) who distinguishes on the one hand between the structure of interest intermediation - pluralism and corporatism (based on Schmitter, 1982) - and, on the other hand, between a strong and a weak state. This results in four types of networks: concertation, sector-based cooperation, intervention, and pressure, each with specific expectations regarding the policy output they produce.

In the case of concertation public and private actors are strongly structured, and their number is limited. The network is not very dense, and centralized around the main actors - both private and public ones. Strongly connected subgroups may appear particularly between the peak associations and state bodies. The (hierarchically organized) interest groups manage their conflicts and coordinate their action with that of the government. These groups face limited competition, and are in a position to 
bargain with the state, because they can offer information and assistance in policy implementation. In return, they are offered a role in policy-making. In the case of sector-based cooperation the few major interest groups become more powerful in comparison to the (numerous) public actors, and the state (partly) depends on interest group(s) (Van Waarden, 1992). Such networks show a medium level of density, and are fairly decentralized and fragmented. In the intervention type, the state acts independently from any social organization, and, consequently, the policy choice will reflect the state preference. The number of state actors is limited while there are many private actors in the network. Networks of this type tend to be relatively dense and centralized around state bodies who accordingly have the power to decide whether and whom to consult. Conversely, the pressure type represents a strong form of pluralism with many different pressure-groups and public actors who all attempt to gain influence. The density of such a network is thus high, but it is not very centralized. The policy choices depend on the actual issue debated and the varying influence of interest groups and public agencies determined by their resources (Smith, 1993). Subgroups may be formed accordingly. Both state agencies and organized interests can dominate the policy choice (Van Waarden, 1992).

\section{Policy network analysis}

Policy network analysis aims at exploring the complex structures of such networks. By focussing on the relations between organisations it explores how strategies and actions brought into play by the network actors influence the results of the policy process. Applying network analysis, various studies have shown that policy networks indeed matter and contribute to understanding policy processes and their results (see, e.g. Daugbjerg, 1998; Greer, 2002; Monpetit, 2005). Marsh and Smith (2000) and Daugbjerg (1998) have pointed in particular to the usefulness of comparative studies. Similarly, in his comparative analysis of biotechnology policies in the United States and Canada, Montpetit (2005) observed a relationship between policy networks and policy results. He chose a 'most-similar-casesresearch' design in order to reduce the influence of factors from the broader political context and the network actors, and, in consequence, could focus on the policy networks to explain policy results. 
We follow this promising approach of a 'most similar systems - most different outcome' research design for our purpose of comparing organic farming policy output in the Czech Republic and Poland.

\section{METHODS}

As basis for the comparison between the two policy networks, quantitative network analyses were carried out in both countries. To reach a meaningful interpretation of the configuration of structures of the Czech and the Polish organic farming policy networks (as independent variable) and to explore their impact on the policy output (as dependent variable) we will use different network characteristics. The classification presented above stresses the importance of network density, the number of private and public actors, their structural organization, centrality, and subgroups. Our analysis takes five structural characteristics of networks into account that illustrate these features. In particular, we will consider: i) the size and density of the network, ii) the distribution of capacities between actors and their structural organization, iii) the cohesion of policy preferences (manifest in subgroups and/or conflicting views on organic farming within the network), iv) the relationship between interest groups and the government, including the centrality of the private actors and state bodies, and v) the dominance of one or more policy networks in a policy field, i.e. in our case, the relationship between the organic and the general agriculture policy networks (see Greer, 2002; Greer, 2005; Montpetit, 2005). In the following, these five network characteristics are explained in more detail.

For a general characterization of the networks, we measured the size, i.e. the number of actors present, and the network density (i). The density thereby is defined as the proportion of links actually established between actors (Kephart, 1950), and varies between a value of zero and one, usually presented as a percentage value. As indicators for the actors' capacities (ii), we consider their (material and non-material) resources, and the degree of organization, in particular of the organic sector. The cohesion of policy preferences (iii) are characterized in two ways. On the one hand, cohesion manifests itself in subgroups, in network jargon called cliques (i.e. a group of mutually linked actors) (Wasserman and Faust, 1999). On the other hand, the issue of cohesion is approached by looking at the conflict structure within the networks. Here, we focus on conflicting opinions of the actors about 
organic farming policy, and analyse their structural equivalence in the conflict network. Through a block modelling procedure actors with a similar relational profile are grouped into one block and the relation between these blocks, or positions, can then be analysed (Burt, 1991; Henning and Wald, 2000). The relationship between interest groups and the agricultural ministry (iv) is explored through the distribution of power, analysed by the reputation and centrality of the actors. Reputation is defined as the expression of the power of an actor, i.e. the perceived power of an actor to have influence in the network. This is measured as the proportion of interviewees who named an actor as influential in relation to a particular policy (Kriesi, 1980; Sciarini 1996). The centrality concept considers actors as powerful if they exert an influence on many others. An actor is central when involved (directly or indirectly) in many relations. In our analysis, we concentrate on the betweenness centrality measure, whereby an actor is central if it lies on the shortest link between other actors (the so-called geodesic), i.e. they have to pass via this actor if they want to interact with each other. A large betweenness centrality signifies that this actor is located between many pairs of actors on their geodesics (Wasserman and Faust, 1999). For purposes of comparison between networks of different sizes, this measure is standardized by dividing the value reached by the maximum possible value of betweenness centrality. Actors with a high betweenness centrality have the potential to control communication within a network and coordinate group processes (Freeman, 1978/79). Hence, this measure describes the potential of a network actor to act as information broker and provides information about its overall activity level and influence in the network. Finally, we analyse the relationship between the organic and the general agriculture policy networks (v) by comparing the reputation of the actors in each of the policy areas.

Network interviews were conducted by local researchers in the native language, using a common questionnaire. A combination of the reputational and positional approaches (Sciarini 1996) was applied to identify potential interviewees. First, invitation lists for parliamentary hearings (or any comparable event) on issues of organic farming were consulted and a list of politically active organizations was produced. Researchers then discussed the list with key persons and identified the most important actors in the domain of organic farming policy; more actors were added if necessary. The final list also included those institutions that are important in the policy process from an 
institutional point of view. In this way, overall, 13 relevant policy actors in the Czech Republic were identified, and 17 in Poland. The interviewees were drawn from state institutions representing the relevant ministries and/or their departments, from the private sector including general and organic farming organizations, environmental interest groups, market organizations, and from other politically important actors. All interviews were carried out in late 2003 / early 2004 and took about one hour. After conducting the interviews, the national researchers submitted the interview results in the form of data matrices to the network analyst. A central analysis of the data ensured a common analysis routine and reduced possible measurement errors. The network analysis was carried out with UCINET software (Borgatti et al. 1999). Visualization of the policy networks was done with Visone software (Brandes \& Wagner 2003), which includes the functionality for graphical representation of actor and network characteristics. The results from the network analysis were written up in country reports and cross-checked with the national experts who had conducted the interviews so as to avoid misinterpretation of the data. To identify the conflict structure in the network, the software application STRUCTURE (Burt 1991) was used. This bases block modelling on hierarchical clustering of the actors (based on the Ward algorithm) and leaves it to the scientist to test the assignments of actors to blocks (Moschitz and Stolze, 2007).

The organic farming policy output in the two countries is described both in terms of policy content, i.e. their main objectives and the instruments chosen (Sciarini, 1994; Dimitrova and Steunenberg, 2000; Bugdahn, 2005) and the timeliness of transposition from EU policy (Giuliani, 2003; Mastenbroek, 2003), i.e. the way in which member states formally incorporate EU legislation into their domestic laws (Michelsen, 2008). In particular, we consider Council Regulation (EEC) No. 2092/91 defining organic agriculture, and Council Regulation (EC) No. 1257/99 providing the basis for financial support of organic farmers.

Policy instruments to support organic farming can be divided into legal, financial or communicative instruments (Van Nispen and Ringeling, 1998). Legal instruments comprise orders, prohibitions and regulations, while financial instruments are less coercive and more stimulative. By contrast, communicative policy instruments involve some kind of interaction between the state and the civil society, and do not include clear sanctions. Information campaigns or strategic documents are 
examples for such communicative policy instruments (Michelsen, 2002). We base our characterization of organic farming policies on the extensive data that Hrabalova et al. (2005) and Tyburski and Zakowska - Biemans (2003) have collected and analysed for the years 1997-2004 in the form of written documents (such as legal texts) and expert information.

\section{ORGANIC FARMING POLICY OUTPUT IN POLAND AND IN THE CZECH REPUBLIC}

\section{Organic farming policy in the Czech Republic}

\section{Objectives}

The objectives of Czech organic farming policy are explicitly mentioned in the 'Action Plan of the Czech Republic for the Development of Organic Farming until 2010', (Resolution of the Government of the Czech Republic No. 236, 2004). This Action Plan conceives of organic farming as 'conforming to the principles of permanently sustainable development of agriculture' (Resolution of the Government of the Czech Republic No. 236, 2004, A. Background, p.4), and assigns it a role in preventing depopulation of the countryside, providing work in primary agricultural production, and contributing to ensuring equitable regional development. The Action Plan combines environmental, economic and social goals. On the one hand, it aims at fostering environmental protection, animal welfare, and the conservation of the countryside. On the other hand, economic goals are highly important. In supporting organic farming, the Czech government wishes to ensure the viability of organic farms and promotes organic farming as a viable livelihood in rural areas. Moreover, it aims to increase the competitiveness of Czech agriculture in the EU through organic farming, expand the market for organic produce and improve the effectiveness of production and processing of organic food. Furthermore, it sets out to enhance public confidence in organic farmers, and envisages better consulting, education and research. Finally, the Action Plan states a target of achieving approx. a 10\% share of organically farmed land by 2010 (Resolution of the Government of the Czech Republic No. 236, 2004).

Legal instruments 
In the Czech Republic, a first national directive on organic farming based on Council Regulation (EEC) No. 2092/91 was introduced in 1993 as a 'Methodological Instruction', 'Metodický pokyn pro ekologické zemedelství c. j. 655/93-340 ze dne 22. cervna 1993' (Ministry of Agriculture, 1993). It provided the legal basis for the national inspection and certification system, and the state label "BIOOrganic Farming Product" was introduced. This directive was replaced in 2001 by Act No. 242/2000 which was an encompassing law, and fully implemented the Council Regulation (EEC) No. 2092/91. To date, this defines the standards for organic farming, processing, labelling and marketing and determines the rules for inspection and certification; Decree No. 53/2001 is the respective executive regulation (Tyburski and Zakowska-Biemans, 2003). At the time it was introduced, Act No. 242/2000 extended beyond Council Regulation (EEC) No. 2092/91 by including measures against contamination with non-organic production (from neighbouring fields), and requirements for packaging materials. The Czech regulation also defined standards for rabbit keeping, aquaculture, viticulture, and for the processing of bee-keeping products, all of which were absent from the then current EU regulation. Furthermore, this regulation was stricter, as many inputs listed in the positive list of the Council Regulation (EEC) No. 2092/91 were not listed in the Czech Act No. 242/2000. However, after EU accession the existing regulations needed little adaptation only, in the form of two executive regulations, Decree No. 263/2003 enlarging the list of allowed inputs and Decree No. 174/2004 extending the list of accepted inspection bodies. Since 2000 (plant production) and 2001 (animal production), the Czech Republic has been listed as a third country provided for in Article 11 (1) of Council Regulation (EEC) No. 2092/91, allowing the export of organic products to the EU.

\section{Financial instruments}

The Czech government began to provide financial support for organic farming in 1990. However, this financial support stopped in 1992 and funds were available again only from 1998 onwards, this time provided under the regime for agri-environmental programmes. From 2001 to 2003, these funds were available through Decree No. 505/2000, later changed to Decree No. 500/2001. Currently, organic farming support is part of the Horizontal Rural Development Plan (Ministry of Agriculture, 2003) and organic farming payments are detailed in Decree No. 242/2004 and its amendments. The Czech government mainly promotes organic farming through area payments to farmers for conversion and 
maintenance, support for information measures and support for inspection and certification. Overall, the Czech Republic spent roughly $€ 7.3 \mathrm{~m}$. on organic farming support in 2003 (€9.5m. in 2004), and the average organic farming payment per supported hectare amounted to $€ 34$ (€43) per ha. All in all, $84(83) \%$ of organically managed land in the Czech Republic was supported in 2003 (2004) (Hrabalova et al., 2005).

\section{Communicative instruments}

In the Czech Republic we find a nationwide state logo for selling organic products which is also promoted by private organizations. Furthermore, an Action Plan on Organic Farming was approved by the Czech government on 17 March, 2004, which was three months ahead of the European Action Plan on Organic Food and Farming (European Commission, 2004). Six policy priorities cover i) the relationship between organic farming, the environment and animal welfare, ii) the strengthening consumer confidence and promotion, iii) processing and marketing, iv) the ability to do business and economic viability, v) research, education and consulting, and vi) policy tools and solutions (Resolution of the Government of the Czech Republic No. 236, 2004). Hence, while not providing financial resources for implementation of measures ${ }^{1}$, the Czech Action Plan is fairly precise and binding ${ }^{2}$.

\section{Organic farming policy in Poland}

\section{Objectives}

In Poland, the objectives of organic farming policy are not stated as clearly as in the Czech Republic. The only indication of such policy goals may be found in the Rural Development Plan which states that organic farming fulfils environmental goals and creates job opportunities in rural areas (Ministry of Agriculture and Rural Development, 2004).

\section{Legal instruments}

\footnotetext{
${ }^{1}$ Financial funds have only been provided recently (Ministry of Agriculture, 2006).

${ }^{2}$ It can be considered clearly more binding than the EU Action Plan (Stolze and Lampkin, 2005).
} 
Poland's first superior law on organic farming based on Council Regulation (EEC) No. 2092/91 was introduced in 2001, by the Act on Organic Farming of 16 March, 2001. It defined organic farming and issued general rules on organic farm management. Subsequently, a number of executive regulations detailed implementation issues (Tyburski and Zakowska-Biemans, 2003). Prior to accession, the Polish legal framework for organic farming deviated from Council Regulation (EEC) No. 2092/91 in two ways. It did not prohibit tie-stalls (which is the case under EU law), and it included extra environmental requirements for farm management (Tyburski and Zakowska-Biemans, 2003). In order to comply fully with EU legislation, the act was replaced just before accession by the Legal Act of April 20, 2004, Journal of Law No. 93, pos. 898. This law was also supplemented by a number of executive regulations coming into force in 2004 (Metera, 2005).

Poland was not placed on the list of third countries provided for in Article 11 (1) of Council Regulation (EEC) No. 2092/91.

\section{Financial instruments}

The Polish government supported the costs of inspection and certification of organic farms from 1998 onwards. Area payments for organic farming (from the second year of conversion on) were introduced in 1999 (Hrabalova et al., 2005; Metera, 2005), and from 2004 onwards, these were provided as part of the agri-environmental programme under the new Rural Development Plan as detailed in the Journal of Law No. 174, pos. 189, Appendix 4 (Ministry of Agriculture and Rural Development, 2004). Currently, organic farming is mainly promoted through area payments to farmers for conversion and maintenance, support for information measures and support for inspection and certification. Overall, the Polish government spent roughly $€ 1.3 \mathrm{~m}$ on organic farming support in 2003 (€7.7m in 2004 when support was provided as part of the agri-environmental programme), and the average organic farming payment per hectare supported amounted to $€ 44$ (€104) per ha. All in all, $62(91) \%$ of the organically managed land in Poland was supported in 2003 (2004) (Hrabalova et al., 2005).

\section{Communicative instruments}


No state logo exists in Poland, and the two private logos are not used nationwide, whereas a few regional programmes for organic farming development have been established since 2002. Until the accession to the EU, no national Action Plan targeting organic farming had been set up ${ }^{3}$.

\section{Comparison of the Czech and the Polish organic farming policy output}

We can conclude that for organic farming policies in both Poland and the Czech Republic, the EU principles and objectives of contributing to environmental quality and cutting excess food production (European Commission, 2000) are relevant, since the national laws are an implementation of EU legislation. Additionally, both countries emphasize organic farming as a source of jobs in rural areas as a reason for supporting this form of land management.

Although both national policies are now equivalent to European law, the Czech organic farming policy is more elaborate than the Polish. Until 2003, the Czech government assigned significantly more funds to organic farming, whereas in Poland substantial organic farming payments started only when they were included in the new rural development plan in the framework of the EU funded rural development programme. Poland has since caught up and, in 2004, the average support for organically farmed land was even higher than in the Czech Republic. An Action Plan on Organic Farming, including clear objectives, has been developed only in the Czech Republic, but not in Poland.

As to timeliness, the Czech government adopted European law much earlier and developed an organic farming policy prior to the accession process to the EU, and its Action Plan had been approved even prior to the EU Action Plan on Organic Farming. In Poland organic farming policy was developed only after the accession process had started.

In sum, the Czech organic farming policy is more elaborate in its content (described by legal, financial and communicative instruments) and has been developed earlier than the Polish organic farming policy.

\footnotetext{
${ }^{3}$ Only in early 2005 did the Ministry of Agriculture begin to set up an Action Plan on organic farming as a response to the Action Plan on Organic Food and Farming developed at the EU (Hrabalova et al., 2005). This process has recently culminated in publication of the Polish Action Plan on Organic Farming for the years 20072013 (Ministry of Agriculture and Rural Development, 2007).
} 
After having presented the organic farming policies in the Czech Republic and Poland, in the following section the organic farming policy networks in the two countries are compared, before we discuss the contribution of the network perspective to explaining policy variation.

\section{COMPARISON OF THE ORGANIC FARMING POLICY NETWORK IN THE CZECH REPUBLIC AND POLAND}

The network analysis focussed on the network question 'With whom do you work together or stay in regular contact in order to exchange your views on organic farming policy?' Figures 1a and $1 \mathrm{~b}$ visualize the Czech and the Polish organic farming policy network with the help of Visone software (Brandes and Wagner, 2003).

Figures $1 a$ and $1 b$ about here

\section{Network size and density}

As Table 1 shows, the Czech organic farming policy network consists of 13 actors. A high proportion of the network actors are private organizations from the organic sector (the organic farming organizations PRO BIO and LIBERA, the association of organic farm advisors EPOS, the inspection and certification body KEZ and the organic market actors COLIFE and GREMA). Only one of the three organizations oriented predominantly towards mainstream farming (the Czech Agrarian Chamber AKCZR) is connected to the network, whereas the farmers' union (ZSCZR) and the association of the food industries (PKCZR) do not closely collaborate with any of the other network members. In addition to the Ministry of Agriculture (MZECZR) which plays a prominent role in the network, the Ministry of Environment (MZPCZR) is also involved in organic farming policy making in the Czech Republic. On average, each actor established 2.1 relations with other actors, resulting in a network density of about $17 \%$, i.e. less than one-fifth of the possible links between actors are present.

The Polish organic farming policy network is larger than the Czech one, and includes 17 actors. In contrast to the Czech network, there are no market actors, more than half of the network actors are state institutions and administrative bodies, and one third are private actors. Only a few actors are oriented towards organic farming. Remarkably, the two organic farming organizations (EKOLAND 
and EKOGAL) play a minor role in the network, whereas the centre is occupied by a mainstreamoriented administrative body, the National Council of Agricultural Chambers (KRIR), and the Institute for Sustainable Development (INER), an actor with an indifferent attitude towards organic farming. As in the Czech Republic, the mainstream farmers' union (KZRKIOR) is only loosely connected to the network. On average, the actors in the Polish network have established more links to each other than in the Czech network, namely 2.8 , and the network density amounts to $17.7 \%$.

\section{Table 1 about here}

\section{Distribution of capacities}

In both countries, the organic farming organizations have poor financial and personnel resources at their disposal for the purpose of engaging in policy making (Moschitz et al., 2004). They are confronted with state actors whose role in the political process is institutionalized, so the distribution of capacities is clearly skewed towards these institutions. All the same, interest groups may build their political engagement upon the considerable level of commitment of their members. If they are able to organise and concentrate the interests of a sector they can build up power and reach a position to bargain with the state. Here, the Czech organic farming sector is in an advantageous position. In the Czech Republic, organic farmers are unified to a large extent under one organic farming organization, PRO BIO, of which about $50 \%$ of all organic farmers are members, whereas in Poland only about $10 \%$ of organic farmers are organized in one of the three organic farming organizations which are scattered across the country and which compete, to some extent, for members and influence (Moschitz et al. 2004).

\section{Cohesion of policy preferences}

Cohesion in a network can be described through cohesive subgroups, such as cliques (i.e. a group of mutually linked actors) (Wasserman and Faust, 1999). Whereas no such subgroup exists in the Polish organic farming policy network, there are two cliques in the Czech network. Both include PRO BIO and KEZ, thus stressing their central position in the network. In one clique, these two actors are joined by the Czech association of organic farmers' advisors (EPOS), while the MZECZR is a member of the 
other. This illustrates well-established contact between important organic sector organizations and the institution in charge of organic farming.

In addition to analysing subgroups, we were interested in the level of conflict in the networks, i.e. the extent to which diverging opinions about organic farming exist (Sciarini et al., 2004). Therefore, the questionnaire included a question on convergent and divergent views on organic farming in relation to the other actors, whereby convergence was coded as " 1 ", divergence as " -1 " and neither nor as " 0 ". The average level of conflict is positive in both networks, but is higher in the Czech case (0.12) than in the Polish case (0.08). A declaration of converging or diverging opinions from those of other network actors presupposes an actor who has made up his or her mind about organic farming, and who has a clear understanding of the views of the other actors. The number of total statements about converging or diverging opinions thus indicates the degree to which the actors could make such an assessment and whether their positions towards organic farming policy are clear. Whereas $30 \%$ of the Czech network actors positioned themselves in relation to the other actors, only $15 \%$ of the Polish network actors declared a clear opinion. Accordingly, the structure of conflict is much clearer in the Czech than in the Polish network. This structure was analysed in detail by block modelling based on structural equivalence in the conflict network. It resulted in meaningful opinion blocks only in the Czech network, whereas no empirical evidence was found for the blocks created by this analytical process in Poland. In the Czech Republic, the inspection body KEZ forms one camp together with PRO BIO and the Ministry of Agriculture. They share opinions on organic farming with each other while declaring divergent views from the "mainstream" network actors (see Table 2). By contrast, in Poland we find a high level of indifference, which indicates that organic farming does not play an important role for most of the actors in the network (see Table 3).

\section{Table 2 about here}

In both Table 2 and 3, each cell gives the average relation from someone occupying position I (given in the row) to someone in position $\mathrm{J}$ (given in the column).

Table 3 about here

Relationship between interest groups and the government 
Such an established relationship between the Czech interest groups for organic farming and the government suggests a general acceptance of these organizations by the state body (see also Moschitz et al. 2004). As has been shown, the same actors not only collaborate with each other on organic farming, but also share the same opinions on organic farming development, expressed by being part of the same opinion block. This high level of acceptance of organic farming organizations in the Czech Republic is mirrored in the process of elaborating the Czech Action Plan on Organic Farming. After it was initiated jointly by KEZ, PRO BIO and MZECZR in 2002, all relevant stakeholders, such as the Ministry of Environment, farmers' organizations, research institutes and other non-governmental organizations, participated in elaborating the Action Plan (Resolution of the Government of the Czech Republic No. 236, 2004; Hrabalova et al., 2005).

The relationship between interest groups and the agricultural ministry is further illustrated by the distribution of power, analysed through the centrality and reputation of the actors. In the Czech network, the most central actor (on the 'betweenness centrality' measure) is PRO BIO, who also scores highly on the reputational power measure (see the left column in Table 4). The agricultural ministry has a high reputation for influencing organic farming policy; however, its betweenness centrality is limited. Thus, organic farming policy in the Czech Republic is dominated by the organic farming organization.

\section{Table 4 about here}

In Poland, the most central actor is the National Council of Agricultural Chambers (KRIR), an administrative body; another environmental organization (INER) which works in organic farming, among other issues, is also fairly central. Remarkably, all of the organic farming organizations have a zero score for betweenness centrality. Although the Agricultural Ministry has a low betweenness centrality score, it is the only actor with a reasonable reputational power (i.e. a score higher than $50 \%$ ) for influencing organic farming policy (see the left column in Table 5) ${ }^{4}$. In summary, organic farming

\footnotetext{
${ }^{4}$ This fairly weak position of the organic sector in the Polish network was exemplified in the more recent process of elaborating an Action Plan on Organic Farming in 2005. In contrast to the Czech Republic, the initiative for such a plan came from the Ministry of Agriculture and was triggered by the EU Action Plan on Organic Food and Farming. The preparation included a number of ministries, such as Environment, Finance, Economic Affairs and Labour, and Science and Information Society Technologies, whereas the organic sector was present only in the form of the six inspection bodies.
} 
policy is dominated by actors outside the organic sector, which have not, for the most part, established a clear opinion on organic farming.

\section{Table 5 about here}

\section{Relationship between organic and general agriculture networks}

The question of dominance of one or more policy networks in organic farming policy is further explored by comparing the reputational networks of the organic and the general policy areas, i.e. we compare the two columns in each of Tables 4 and 5.

In the Czech Republic, organic farming represents a distinctive policy field. Apart from the Agricultural Ministry which has an institutional role, no actor is seen as influential both on organic farming policy and on general agricultural policy. Organic sector organizations dominate the organic farming policy network, whereas the mainstream farming institutions and organizations influence the general agricultural policy network. In Poland, too, the Agricultural Ministry is powerful in both policy networks for institutional reasons. But, in contrast to the Czech case, its power in organic farming policy is not balanced by organic farming organizations. In consequence, organic farming policy is not clearly distinct from general agricultural policy, and both policy areas are dominated by the Agricultural Ministry. The results from block modelling, as shown above, support this finding.

\section{Summary: brief comparison of the Czech and the Polish organic farming policy network}

Comparing the Czech and the Polish organic farming policy network, we can see that the Czech network is smaller, i.e. fewer policy actors are relevant to the shaping of organic farming policy. By contrast, Polish organic farming policy is shaped by a larger number of actors and a strong state. Overall, the policy actors are less engaged in the policy-making process. The difficulties caused by the lack of financial resources which organic farming interest groups in both countries face are reduced in the Czech network by a strongly unified organic sector committed to political action. In Poland, organic farming organizations are scattered across the country, and conflicts among them hamper collective political action. The most remarkable difference between the two networks is the clear preference for organic farming in the Czech network in contrast to the prevailing indifference towards 
organic farming in the Polish network. Not only are many more organic actors involved in organic farming policy making in the Czech Republic, but the most central position is also taken by the organic farming organization, giving it a strong position vis-à-vis the government. In Poland, the organic farming organizations have not managed to become recognized as important policy actors in the network. In sum, the Czech organic farming policy network comes close to a concertation network type as it has been characterized at the beginning of this paper. By contrast, the Polish organic farming policy network can be characterized as intervention type (Kriesi, 1994). In addition, the organic farming policy network is distinct from the general farming network in the Czech Republic whereas in Poland organic farming is strongly influenced by the general farming policy network.

The following section uses the comparison of the policy networks in the two countries to show how the different themes of network analysis contribute to explaining the variation in these policy outputs.

\section{THE RELATION BETWEEN NETWORKS AND OUTPUT}

Organic farming is widely preferred in the Czech network. A large number of organic actors are members of the network, but the organic sector is well organized and has successfully used its capacity of a common identity in the policy-making process. It has established a relatively strong position vis-à-vis the state bodies. Evidence for this success could be found at various occasions. From the early 1990s on, just after the breakdown of the socialist system, organic farming interest groups lobbied for an organic farming legislation, including financial support, which became available for a first time from 1990 to 1992 . The organic sector organizations were also successful in promoting the export of organic products into the EU by lobbying for a control and certification body as a public benefit organization which was a prerequisite for approval to the list of third countries provided for in Article 11 (1) of Council Regulation (EEC) No. 2092/91. Furthermore, on their initiative, the discussion process on an Action Plan for Organic Farming started in 2002, and was supported by the Agricultural Minister of the Czech Republic. The involvement of the organic farming organizations throughout the development process of this Action Plan until its publication in 2004 is acknowledged in the introductory part of the Czech Action Plan: 'The plan [...] was prepared particularly in 
cooperation with the representatives of unions of organic farmers (PRO-BIO, Libera), the controlling body KEZ o.p.s., agricultural universities, research institutes and with the organic farmers, processors and distributors of biofood.' (Resolution of the Government of the Czech Republic No. 236, 2004, p.2). Thus, the main organic farming organization occupying the central position in the network influences policy, shapes the preferences that are formulated and discussed in the network, and in this way adds to the recognition of organic farming. The representatives of the organic sector had a strong interest in bringing organic farming into the political discourse and were successful in doing so.

By contrast, in Poland the organic sector is less equipped for political action, and much less organized, while being confronted with a political environment that is less clear towards organic farming issues. The political discourse on organic farming has been triggered out of a need to comply with developments at the EU level rather than in response to domestic pressure from an interest group. The organic farming interest groups have not succeeded in establishing a clear position vis-à-vis the state bodies that would be recognized by the latter. In consequence, the organic farming policy in Poland is much more state driven than in the Czech Republic. At the same time, organic farming is not a high priority on the political agenda of the Polish Agricultural Ministry (Moschitz et al., 2004).

\section{CONCLUSION}

Applying a "most similar systems - most different outcome" research design, this paper has shown how the common themes of network analysis we used to illustrate the structural characteristics of networks can contribute to explaining variation in policy output. In particular, the size and density of the network, the distribution of capacities between actors and their structural organization, the cohesion of policy preferences, and the relationship between interest groups and the government proved to be relevant.

In the concertation-type organic farming policy network of the Czech Republic organic farming policy is discussed mainly between the government and the major organic farming organization to which the organic interest groups have delegated the competence to politically represent the whole sector. Hence, the organic sector acts as a cohesive group and defends a clear position towards the state bodies. It is 
thus able to counterbalance the institutionalized power of the government. The close relationship between the major organic farming organization and the agricultural ministry is shown in that it assists in policy implementation, and provides state agencies with information. This situation has lasted since, what can be seen from the fact that recently, this organic farming organization contributed to the 2006 Yearbook on Organic Farming in the Czech Republic edited by the Czech Agricultural Ministry (PRO-BIO and Bioinstitut o.p.s, 2006).

Conversely, the Polish organic farming policy interest intermediation can be characterized as an ‘intervention’ type. More actors interact with a higher density, but without a clear structure. Organic farming policy is dominated by the state while the organic sector does not have enough resources to effectively participate in the policy-making process. It lacks cohesion, and is not well organized. Consequently, the organic farming organizations experience difficulties in becoming heard and establishing a clear position against the government. Given such a network, the little interest of the dominating (state) actor in organic farming explains why organic farming policy is less elaborate in Poland than in the Czech Republic.

Admittedly, the static tool of network analysis produces a picture of one specific moment in a policy process. However, relatively young policy fields, such as organic farming policy in the new EU member states, are in general fairly dynamic and prone to change. Different actors may take the central position at different times and determine the prevailing discourse and preferences in a network. Thus, other organic farming policy networks in the new EU member states or, at some other point in time, the networks described here may lie somewhere between the two 'extreme' cases (in terms of policy output) presented in this paper. 
Number of words: 6964

Acknowledgements

To be completed 


\section{References}

Borgatti, S.P., Everett, M.G., Freeman, L.C. 1999. UCINET 6.0 Version 1.00. Analytic Technologies, Natick.

Brandes, U., Wagner, D., 2003. visone - Analysis and Visualization of Social Networks. In: Jünger, M., P. Mutzel (Eds.). Graph Drawing Software. Springer-Verlag, Berlin, pp. 321-340.

Bugdahn, S., 2005. Of Europeanization and domestication: the implementation of the Environmental Information Directive in Ireland, Great Britain and Germany. Journal of European Public Policy 12, 177-199.

Burt, R. S., 1991. Structure. 4.2. Reference Manual. Columbia University. New York.

Daugbjerg, C., 1998. Policy networks under pressure: pollution control, policy reform and the power of farmers. Ashgate, Aldershot.

Dimitrova, A., Steunenberg, B., 2000. The Search for Convergence of National Policies in the European Union. An Impossible Quest? European Union Politics 1, 201-226.

European Commission, 2000. Organic Farming. Guide to community rules. Office for Official Publications of the European Communities, Luxembourg.

European Commission, 2004. European Action Plan for Organic Food and Farming. Communication from the Commission to the Council and the European Parliament. SEC(2004)739.

Freeman, L. C., 1978/79. Centrality in Social Networks. Conceptual Clarification. Social Networks 1, 215-239.

Giuliani, M., 2003. Europeanization in Comparative Perspective; Institutional Fit and National Adaptation. In: Featherstone, K., C. M. Radaelli (Eds.). The Politics of Europeanization. Oxford University Press, Oxford, pp. 134-157.

Greer, A., 2002. Policy Networks and Policy Change in Organic Agriculture: A comparative analysis of the UK and Ireland. Public Administration 80 (3), 453-473.

Greer, A., 2005. Agricultural policy in Europe. European Policy Research Unit Series. Manchester University Press, Manchester. 
Henning, C. H. C. A., Wald, A., 2000. Zur Theorie der Interessenvermittlung: Ein Netzwerkansatz dargestellt am Beispiel der Gemeinsamen Europäischen Agrarpolitik. Politische Vierteljahresschrift 41 (4), 647-676.

Hrabalova, A., Handlova, J., Koutna, K., Zdrahal, I., 2005. Final report on the development of organic farming in ten selected CEE countries with national report cards. EU-CEE-OFP. Further Development of Organic Farming Policy in Europe with Paricular Emphasis on EU Enlargement. Project report. Prague.

Kephart, W. M., 1950. A quantitative analysis of intragroup relationships. American Journal of Sociology 55, 544-549.

Knoke, D., 1996. Comparing Policy Networks. Labor politics in the U.S., Germany and Japan. Cambridge University Press, New York.

Kriesi, H., 1980. Entscheidungsstrukturen und Entscheidungsprozesse in der Schweizer Politik. Campus, Frankfurt a. Main.

Kriesi, H., 1994. Les démocraties occidentales. Une approche comparé. Economica, Paris.

Marin, B., Mayntz, R., 1991. Introduction: Studying Policy Networks. In: Marin, B., R. Mayntz (Eds.). Policy Networks. Empirical Evidence and Theoretical Considerations. Campus Verlag, Frankfurt a. Main, pp. 11-23.

Marsh, D., Smith, M., 2000. Understanding policy networks: towards a dialectical approach. Political Studies 48 (1), 4-21.

Mastenbroek, E., 2003. Surviving the Deadline: The Transposition of EU Directives in the Netherlands. European Union Politics 4 371-395.

Metera, D., 2005. Organic Farming in Poland: Update July 2005. (FiBL), http://www.organiceurope.net/country_reports/poland/default.asp\#8. accessed: 10.01.2007.

Michelsen, J., 2002. Organic Farming Development in Europe - Impacts of Regulation and Institutional Diversity. In: Hall, D. C., J. L. Moffitt (Eds.). Economics of Pesticides, Sustainable Food Production, and Organic Food Markets 4. Elsevier, pp. 101-138.

Michelsen, J., 2008. A Europeanization deficit? The impact of EU organic agriculture regulations on new member states. Journal of European Public Policy 15 (1), 117-134. 
Ministry of Agriculture, 1993. Metodický pokyn pro ekologické zemedelství c. j. 655/93-340 ze dne 22. cervna 1993.

Ministry of Agriculture, 2003. Horizontal Rural Development Plan of the Czech Republic 2004-2006. http://www.mze.cz/attachments/HRDP-04-06.doc. accessed: 23.06.2007.

Ministry of Agriculture, 2006. Prubežná zpráva o plnení Akcního plánu CR pro rozvoj ekologického zemedelství do roku 2010.

Ministry of Agriculture and Rural Development, 2004. Plan Działań dla Żywności Ekologicznej i Rolnictwa w Polsce na lata 2004-2006. http://www.minrol.gov.p1/FileRepozytory/FileRepozytoryShowImage.aspx?item_id=11971. accessed: 23.06.2007.

Ministry of Agriculture and Rural Development, 2007. Plan Działań dla Żywności Ekologicznej i Rolnictwa w Polsce na lata 2007-2013. Warsaw.

Montpetit, E., 2005. A Policy Network Explanation of Biotechnology Policy Differences between the United States and Canada. Journal of Public Policy 25 (3), 339-366.

Moschitz, H., Stolze, M., 2007. Policy networks of organic farming in Europe. Organic Farming in Europe: Economics and Policy 12. University of Hohenheim, Stuttgart.

Moschitz, H., Stolze, M., Michelsen, J., 2004. Report on the development of political institutions involved in policy elaborations in organic farming for selected European states. EU-CEEOFP. Further Development of Organic Farming Policy in Europe with Paricular Emphasis on EU Enlargement. Project report. Frick.

Prazan, J., Koutna, K., Skorpikova, A., 2004. Development of Organic Farming and the Policy Environment in Central and Eastern European Accession States, 1997-2002. EU-CEE-OFP. Further Development of Organic Farming Policy in Europe with Paricular Emphasis on EU Enlargement. Project report. Prague.

PRO-BIO, Bioinstitut o.p.s, 2006. Organic Farming in the Czech Republic. 2006 Yearbook. Praha. Resolution of the Government of the Czech Republic No. 236, 2004. Action Plan of the Czech Republic for the Development of Organic Farming until 2010. 
Rhodes, R. A. W., Marsh, D., 1992. New directions in the study of policy networks. European Journal of Political Research 21, 181-205.

Schmitter, P. C., 1982. Reflections on Where the Theory of Neo-Corporatism Has Gone and Where the Praxis of Neo-Corporatism May Be Going. In: Lehmbruch, G., P. C. Schmitter (Eds.). Patterns of Corporatist Policy-Making. Sage, Beverly Hills, pp. 259-279.

Sciarini, P., 1994. La Suisse face à la Communauté européenne et au GATT. Le cas-test de la politique agricole. Georg, Genève.

Sciarini, P., 1995. Réseau politique interne et négotiations internationales: le GATT, levier de la réforme agricole suisse. Swiss Political Science Review 1 (1), 1-29.

Sciarini, P., 1996. Elaboration of the Swiss Agricultural Policy for the GATT Negotiations: a Network Analysis. Schweizerische Zeitschrift für Soziologie 22 (1), 85-115.

Sciarini, P., Fischer, A., Nicolet, S., 2004. How Europe hits home: evidence from the Swiss case. Journal of European Public Policy 11 (3), 353-378.

Smith, M. J., 1993. Pressure, Power and Policy: State Autonomy and Policy Networks in Britain and the United States. Harvester Wheatsheaf, London.

Stolze, M., Lampkin, N. H., 2005. Einbettung des ökologischen Landbaus in die EU-Agrarpolitik Der EU-Aktionsplan für den ökologischen Landbau. Agrarwirtschaft und Agrarsoziologie (1), $57-68$.

Stolze, M., Lampkin, N. H., 2009. Policy for organic farming: Rationale and concepts. Food Policy 34 (3), 237-244.

Tyburski, J., Zakowska-Biemans, S., 2003. Report on Harmonisation of Regulations and Standards for Organic Agriculture in the Central and Eastern Europe Accession Countries and the European Union. EU-CEE-OFP. Further Development of Organic Farming Policy in Europe with Paricular Emphasis on EU Enlargement. Project Report. Warsaw.

Van Nispen, F. K. M., Ringeling, A. B., 1998. On instruments and instrumentality: a critical assessment. In: Peters, G. B., F. K. M. Van Nispen (Eds.). Public Policy Instruments. Evaluating the Tools of Public Administration. Edward Elgar Publishing Ltd, Cheltenham, pp. 204-221. 
Van Waarden, F., 1992. Dimensions and types of policy networks. European Journal of Political Research 21 (1-2), 29-52.

Wasserman, S., Faust, K., 1999. Social Network Analysis: Methods and Applications. Cambridge University Press, New York.

\section{Acknowledgement}

The authors are grateful to Andrea Hrabalova, Jaroslav Prazan, Sylwia Zakowska-Biemans, Andrzej Szeremeta, and Krystyna Gutkowska who carried out the interviews in the Czech Republic and Poland and discussed the results of the national analyses. We would like to thank Pascal Sciarini, Bernard Lehmann and Sophie Réviron for their helpful comments, as well as the anonymous referees. The research was financially supported by the Commission of the European Community as part of the EUCEEOFP project (QLK5-2002-00917) and the Swiss State Secretariat for Education and Research. The views expressed are the authors' and do not necessarily reflect the views of the Commission, nor do they anticipate future policy in this area. 
TABLE 1 Main characteristics of the Czech and the Polish organic farming policy network

\begin{tabular}{lll}
\hline Network measure/parameter & Czech Republic & Poland \\
\hline Size & 13 & 17 \\
Density & $17.3 \%$ & $17.7 \%$ \\
Actor types & & \\
$\quad$ State & 2 & 7 \\
$\quad$ Private & 10 & 6 \\
$\quad 1$ & 1 & 4 \\
Others & & \\
$\quad$ Predominant orientation of actors & 6 & 3 \\
$\quad$ Oriented towards organic & 6 & 8 \\
$\quad$ Indifferent or balanced orientation towards mainstream & 4 & 6 \\
\hline
\end{tabular}

Source: Moschitz and Stolze, 2007 
TABLE 2 Structural equivalence analysis: Convergence/divergence network of opinions on organic farming in the Czech Republic

\begin{tabular}{lllll}
\hline Position & $\mathbf{1}$ & $\mathbf{2}$ & $\mathbf{3}$ & Residual \\
\hline $\mathbf{1}$ & 0.167 & 0.111 & 0 & -0.111 \\
$\mathbf{2}$ & -0.889 & 1 & 0.167 & 0.222 \\
$\mathbf{3}$ & -0.333 & 0.417 & 0.083 & 0 \\
Residual & 0 & 0.889 & 0.333 & 0.333 \\
\hline
\end{tabular}

Average density: 0.12

Notes:

Position 1 = “mainstream organizations” (ZSCZR, AKCR, PKCZR)

Position 2 = "policy makers” (PRO BIO, KEZ, MZECZR)

Position 3 = “actors open to organic farming” (GREMA, ASZ, EPOS, COLIFE)

Residuals = LIBERA, MZPCZR, VUZEPR

TABLE 3 Structural equivalence analysis: Convergence/divergence network of opinions on organic farming in Poland

\begin{tabular}{llllll}
\hline Position & $\mathbf{1}$ & $\mathbf{2}$ & $\mathbf{3}$ & $\mathbf{4}$ & Residual \\
\hline $\mathbf{1}$ & 0 & 0,1 & 0 & 0 & 0 \\
$\mathbf{2}$ & 0 & 0 & 0.071 & 1 & 0 \\
$\mathbf{3}$ & -0.086 & 0.286 & 0.095 & -0.571 & 0 \\
$\mathbf{4}$ & 0 & 0 & 0 & 0 & 0 \\
Residual & 0.8 & 0.5 & 0.5 & 1 & -0.5 \\
\hline
\end{tabular}

Average density: 0.08

Notes:

Position 1 = "state institutions" (SLD, SKRIRW, SEKRIRW, ARIMR, IJHARS)

Position 2 = "central actors" (KRIR, INER)

Position 3 = "environmentally interested" (EKOLAND, PZ, KNRRRE, KZRKIOR, PKE, MS, EKOGAL)

Position 4 = "ministry" (MRIRW)

Residuals $=$ PSL, PO 
TABLE 4 Reputational power of network actors for organic farming and general farming policy in the Czech Republic

\section{Organic farming policy}

Agricultural Ministry (100\%)

Pro Bio - organic farming organization (100\%)

\section{General farming policy}

Agricultural Ministry (100\%)

Research Institute of Agricultural Economics, Prague (69\%)

KEZ (inspection body for organic agriculture) Czech Agrarian Chamber (62\%) $(92 \%)$

Environmental Ministry (85\%)

Source: own data

TABLE 5 Reputational power of network actors for organic farming and general farming policy in

Poland

\begin{tabular}{ll}
\hline Organic farming policy & General farming policy \\
\hline Agricultural Ministry (94\%) & Agricultural Ministry (94\%) \\
& $\begin{array}{l}\text { Agency for Restructuring and Modernization of } \\
\text { Agriculture (59\%) } \\
\text { Agriculture and Rural Development Committee } \\
\text { of the Polish Parliament (53\%) }\end{array}$ \\
\end{tabular}

Source: own data 

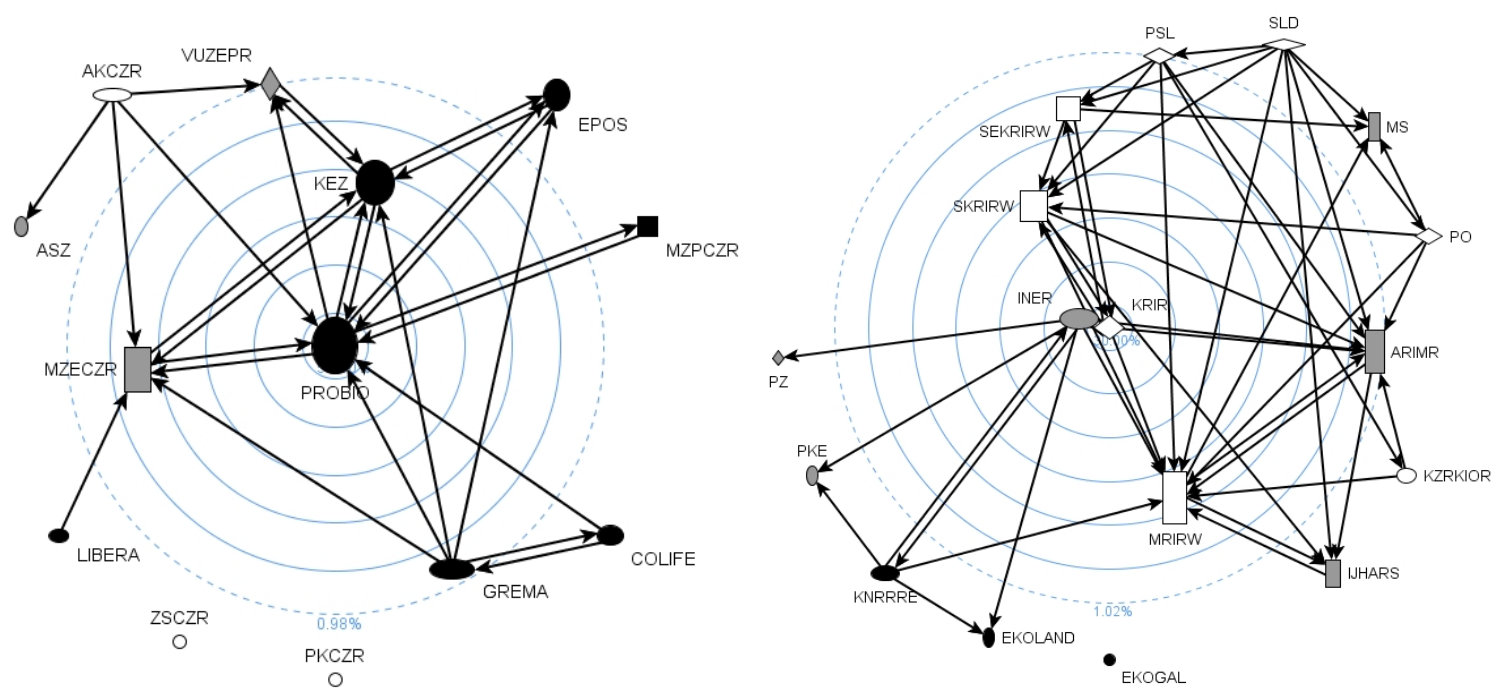

FIG.1Organic farming policy network in the Czech Republic (a) and Poland (b)

Abbreviations

AKCZR Czech Agrarian Chamber

ASZ Association of private farmers

COLIFE Czech branch of Country Life Ltd. - a whole food retailer

EPOS Czech association of advisors for organic farming

GREMA Organic products marketing company

KEZ Czech inspection body for organic farming

LIBERA Organic farming organization

MZECZR Ministry of Agriculture of the Czech Republic

MZPCZR Ministry of Environment of the Czech Republic

PKCZR Federation of food and drink industries

PROBIO Organic farming organization

VUZEPR Research Institute of Agricultural Economics in Prague

ZSCZR Czech farmers' union

$\begin{array}{ll}\begin{array}{ll}\text { ARIMR } \\ \text { EKOGAL }\end{array} & \begin{array}{c}\text { Agency for Restructuring and Modernization of Agriculture } \\ \text { Organic farming organization in the Subcarpathian } \\ \text { region }\end{array} \\ \text { EKOLAND } & \begin{array}{l}\text { Organic farming organization } \\ \text { IJHARS }\end{array} \\ \text { INER } & \begin{array}{l}\text { Agriculture and Food Quality Inspection } \\ \text { Institute for Sustainable Development }\end{array} \\ \text { KNRRRE } & \text { Coalition for the Organic Farming Development } \\ \text { KRIR } & \text { National Council of Agricultural Chambers } \\ \text { KZRKIOR } & \text { Polish farmers' union } \\ \text { MRIRW } & \text { Ministry of Agriculture and Rural Development, } \\ & \text { Department of Plant Breeding and Protection, } \\ \text { MS } & \text { Organic Farming Unit } \\ \text { PKE } & \text { Ministry of the Environment } \\ \text { PO } & \text { Polish Ecological Club } \\ \text { PSL } & \text { Civic Platform } \\ \text { PZ } & \text { Polish People's Party } \\ \text { SEKRIRW } & \text { Polish Green Party } \\ \text { SKRIRW } & \text { Agriculture and Rural Development Committee of the } \\ & \text { Polish Senate } \\ \text { SLD } & \text { Agriculture and Rural Development Committee of the } \\ & \text { Polish Parliament } \\ \text { Democratic Left Alliance Party }\end{array}$

Notes: In Figures $1 \mathrm{a}$ and $1 \mathrm{~b}$, the actors' size indicates the number of direct links an actor is involved in, i.e. in network jargon, its degree value, whereby the vertical extent refers to the links sent out, and the horizontal extent to the links received. The actors are ordered on the circles according to their betweenness centrality values, with the most central actor in the centre of the inner circle.

The shape of the node illustrates the actor type:

$$
\begin{aligned}
& O_{\text {or }} \mathrm{O}_{\text {or }} \bigcirc \text { : private organisation } \\
& \square \text { or } \square \text { or } \square \text { : state institution } \\
& \curlyvee^{\text {or }}\langle\text { or } \longleftrightarrow \text { : other organisation or institution (often parastatal) }
\end{aligned}
$$

The colour of the actor node indicates its classification by the experts:

- black: predominantly oriented to organic farming

white: predominantly oriented to mainstream farming

grey: balanced or undefined 